\title{
DEFINING THE CONCEPTS \& APPROACHES IN VERNACULAR ARCHITECTURE STUDIES
}

\author{
Ali Asadpour*1 \\ Assistant Professor, Department of Interior Architecture, Shiraz University of Arts, Iran ${ }^{1}$ \\ e-mail: *1asadpour@shirazartu.ac.ir
}

\begin{abstract}
Abstrak_ Makalah ini membahas arsitektur vernakular dalam hal konsep dan pendekatan dalam studi. Keragaman definisi, sikap, dan preferensi telah menghasilkan berbagai pendekatan dalam beberapa dekade terakhir. Mengenali perbedaan ini dapat membantu untuk mendapatkan pemahaman yang lebih dalam tentang kondisi saat ini dan cakrawala masa depan dalam penelitian. Tujuan dari penelitian ini termasuk mengidentifikasi dan mengkategorikan pendekatan dominan terhadap arsitektur vernakular. Metode penelitian yang digunakan adalah kualitatif dan deskriptif. Hasil penelitian mengidentifikasi lima kecenderungan yang dianggap arsitektur vernakular sebagai objek estetika, fenomena biologis (jenis dan evolusi), substansi material-fisik (penjelasan fisik), realitas budaya-sosiologis, dan akhirnya sebagai fenomena antropologis. Pendekatan-pendekatan ini merepresentasikan perpindahan dari dokumentasi ke interpretasi, objektivitas ke subjektivitas, dan primitif ke biasa dalam studi. Fenomenologi, hermeneutika, semiotik, studi gender, dan feminisme menetapkan cakrawala baru bagi penelitian arsitektur vernakular. Evolusi sikap dapat dijelaskan di bawah perubahan paradigma penelitian dari positivisme ke post-positivisme dan fenomenologi.
\end{abstract}

Kata kunci: Arsitektur Vernakular; Desain Iklim; Budaya; Sosiologi; Tipologi.

\begin{abstract}
This paper addresses vernacular architecture in terms of concepts and approaches in studies. The diversity of definitions, attitudes, and preferences has led to a variety of approaches in recent decades. Recognizing these differences can help to obtain a deeper understanding of today's conditions and future horizons in research. The objectives of this study included identifying and categorizing the dominant approaches toward vernacular architecture. The research used a qualitative and descriptive method. The results identified five tendencies considered vernacular architecture as an object of aesthetics, a biological phenomenon (types and evolution), a materialphysical substance (physical explanations), a cultural-sociological reality, and finally as an anthropological phenomenon. These approaches represented the movement from documentation to interpretation, objectivity to subjectivity, and primitive to ordinary in the studies. Phenomenology, hermeneutics, semiotics, gender studies, and feminism set new horizons for vernacular architectural research. The evolution of attitudes can be explained under the change in research paradigms from positivism to post-positivism and phenomenology.
\end{abstract}

Keywords: Vernacular Architecture; Climatic Design; Culture Sociology; Typology.

\footnotetext{
${ }^{1}$ Assistant Professor, Department of Interior Architecture, Shiraz University of Arts, Iran
} 


\section{INTRODUCTION}

Modernism neglected vernacular architecture, and this condition continued to the middle of the twentieth century until little attention paid to that rapidly declining legacy (Oliver 1996, 12). In general, vernacular architecture had a marginal place in research, profession and education at the beginning of the last century (Lanier 2009). A small part of the architecture profession or the education paradigm instructed us to look at the architecture of the scene of traditional social values. Modernism which is the philosophical basis of many architecture schools is also intrinsically combined with positivism, idealism, and rationalism (Mann 1985, 10).

Furthermore, there is no agreement on the meaning of vernacular; the conventional understanding of this term is equivalent to the word native meaning one's belonging to the land in which he/she was born (Ashish Ganju 2016, 1). The synonyms of this word are also varied; anonymous, popular, indigenous, primitive, spontaneous, every day, and shared are parts of these expressions (Lawrence 2013, 19). Being local means being fit to our needs. Almost all buildings stay fixed in place, and they embodied the subject of placement. But there is also a social context in which the architectural structure is also a part. Here the second issue, shared derived from context and culture. Shared, by definition, requires a group of people in the past or present that have enormous bonds with each other. Distinctive buildings also find native characters for their creators and users in a particular community. Instead of sharing its nearest synonym, common can be used (Garfinkel 2006, 109). J. B. Jackson once quoted that a structure or object would be purely vernacular when it becomes, or is, of a place (Heath 2003, 51). This interpretation of Jackson has a meaningful relation to what was called local and illustrates the importance of place and planeness in the vernacular term, which contradicts the universalism beliefs of early modernism.

The variety of meanings and notions of vernacular architecture suggests that scholars may lack studies that can categorize fundamental trends and concepts in vernacular architecture and could donate them with new research possibilities. This condition occurred, especially in developing countries or nations with less research on vernacular architecture. Therefore, the main objective of this study is to discuss and categorize the approaches toward vernacular architecture to provide a framework for further in-depth researches. The results of this study can give a big picture of the subject in front of the eye and also show new horizons for future studies.

\section{METHOD}

The research utilizes a qualitative and descriptive inquiry. At first, the vernacular architecture definitions discussed and the dominant viewpoints analyzed to take a new look at the notion in comparison to its common meanings. Then, by reviewing relevant studies in the field of vernacular architecture, the approaches identified and categorized. For each category, examples also are given to illustrate how these concepts are applied. Of course, there are many other tendencies of this issue, but categorizing has been made in a way that it reveals opportunities in the field of vernacular architecture research.

\section{A. Vernacular Architecture Definitions}

Giuseppe Pagano was the first to find a name for vernacular architecture and call it "spontaneous architecture", not in a random but in a natural sense (Alpago Novello 2005, 25) but Paul Oliver was one of the first scholars to devote much time to research on vernacular architecture, typology, and related definitions, and the English word vernacular has also come to architecture through his efforts in the field of linguistics (Damyar and Nari Ghomi 2012, 72, Oliver 1996). Oliver's definition of vernacular architecture encompasses a variety of meanings; from constructions built or adapted by people to their daily needs in any time and place, to 
more limited definitions of traditional mansions, pre-industrial and hand-built structures. The reason for this variety is that Oliver considered buildings as objects belonging to a particular type of vernacular constructions; such as straw warehouses, windmills, village chapels, workshops, or traditional houses, but at the same time, he regarded the vernacular as a process of change and adaptation by the people in the specific situations that could involve modern materials and structures too (Cromley 2008, 302). This interpretation of vernacular architecture based on the process of change and adaptation was a new idea that was less favoured by researchers in the field of vernacular architecture, and has many opportunities for contemporary interventions.

Some experts have conservative attitudes. For instance, Eric Mercer (1997) argued that vernacular buildings are those that belong to a group of constructions that were common in a particular region and time. In other words, no building is considered to be vernacular because of its qualities, but rather by virtue that is shared by many. In his interpretation, we can also see a kind of environmental limitation; where he speaks of a particular region and time, he refers to temporal-spatial boundaries. Brunskill's (1981) interpretation emphasizes a kind of dichotomy between academicism and traditionalism. He employs words such as simple, local, persistent, and emotionally versus temporary, arid and transient that represents modern design practices and design academy instructions. Other definitions in Table 1 also refer to some form of vernacular architecture defined against formal architecture and aesthetics. Vernacular architectures are buildings that are exquisite, intimate, practical, daily used, in conjunction with the place and based on the needs and feelings of their inhabitants, based on vernacular tradition. However, the briefest new definition of vernacular architecture can be found in the words of Dell Upton, who writes in paper: the vernacular building is ordinary building (Groth 1999, 444). Such an interpretation would allow ordinary or everyday buildings, which are free from the principles and laws of the elite class to be considered vernacular even in contemporary times (Figure 1).

Table 1. Definitions of Vernacular Architecture

\begin{tabular}{|c|c|c|c|}
\hline No & Researcher & Date & Definition \\
\hline 1 & Eric Mercer & 1975 & $\begin{array}{l}\text { Vernacular buildings are those that belong to a group of constructions that were } \\
\text { common in a particular region and time... In other words, no building is considered to } \\
\text { be vernacular because of its qualities, but rather by virtue that is shared by many. }\end{array}$ \\
\hline 2 & $\begin{array}{c}\text { R.W. } \\
\text { Brunskill }\end{array}$ & 1981 & $\begin{array}{l}\text { Vernacular buildings are kinds of constructions that are consciously sustained instead } \\
\text { of temporary, have traditional inspirations instead of being academic, and designed to } \\
\text { feed the simple, day-to-day activities of the people, their farm and their modest } \\
\text { industrial business. They are gradually dependent on location and the use of local } \\
\text { building materials but reflect the design and construction of an emotionally and } \\
\text { thoughtful building rather than being designed and constructed on a practical } \\
\text { application basis. }\end{array}$ \\
\hline 3 & Camille Wells & 1982 & $\begin{array}{l}\text { Vernacular architecture encompasses a variety of buildings, including factories, farms } \\
\text { and homes - schools and separate homes with all its sights, mills, agricultural areas, } \\
\text { fields around towns and business strips. }\end{array}$ \\
\hline 4 & Dell Upton & 1985 & Vernacular buildings are ordinary buildings. \\
\hline 5 & $\begin{array}{l}\text { Kingston } \\
\text { W.m. Heath }\end{array}$ & 1988 & $\begin{array}{l}\text { Vernacular architecture is a craft whose value is not in style but its capacity as cultural } \\
\text { messaging. }\end{array}$ \\
\hline 6 & $\begin{array}{l}\text { Judith } \\
\text { Roberts }\end{array}$ & 1996 & $\begin{array}{l}\text { Vernacular architecture means building with local materials based on local traditions } \\
\text { through shapes and forms of construction of shelters and buildings that have become a } \\
\text { document of economic and social processes. It is through the layout of form, materials, } \\
\text { patterns, and details that we are now able to 'read' these buildings and understand } \\
\text { them in our place. }\end{array}$ \\
\hline 7 & Paul Oliver & 2000 & $\begin{array}{l}\text { Vernacular architecture means a building of people, making them by the people. } \\
\text { Vernacular architecture does not refer to buildings designed and built by professional } \\
\text { architects and builders. }\end{array}$ \\
\hline 8 & $\begin{array}{c}\text { Maria } \\
\text { Philokyprou }\end{array}$ & 2011 & $\begin{array}{l}\text { Vernacular architecture generally refers to a local and unknown architecture that } \\
\text { responds to local needs through a form that is flow function. While aesthetics and } \\
\text { decorations are prominent in official buildings, vernacular settlements are devoid of }\end{array}$ \\
\hline
\end{tabular}




\begin{tabular}{cl}
\hline & $\begin{array}{l}\text { these. Their importance is due to their continued use and reuse, as living and using } \\
\text { them are essential for keeping the vernacular traditions alive. }\end{array}$ \\
\hline $9 \quad \begin{array}{l}\text { Juan A. } \\
\text { García- } \\
\text { Esparza }\end{array}$ & $\begin{array}{l}\text { In vernacular architecture, the subject attempts to identify historical objects through } \\
\text { his/her imagery and perception of the enduring region, memory, and effects. All of this } \\
\text { is affected by the feelings and emotions of each viewer. }\end{array}$ \\
\hline Source: (Mercer 1997, Brunskill 1981, Cromley 2008, 302, García-Esparza 2015, Groth 1999, 444, Heath 2003, 49, Philokyprou
\end{tabular}

2011, 8, Roberts 1996, 177)

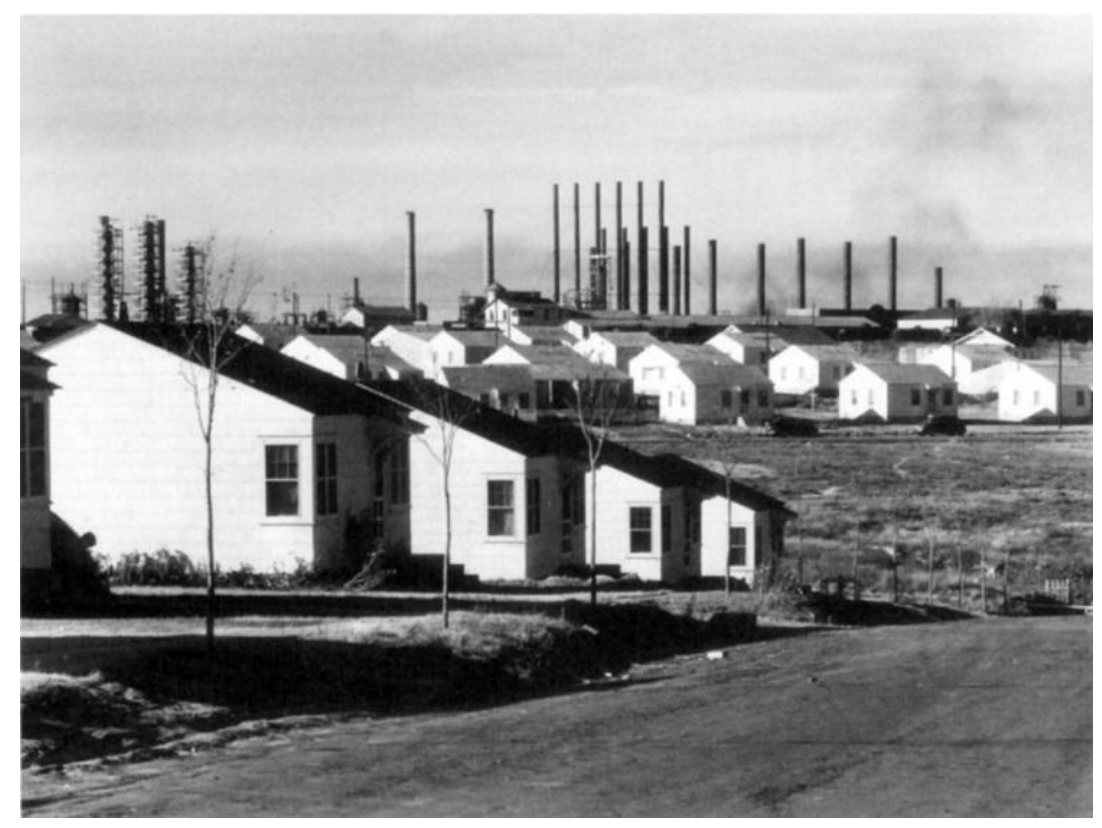

Figure 1. Workers' Houses and the Phillips Oil Refinery, Texas Source: Groth $(1999,446)$

Amos Rapoport and his disciples coined "folk" or "popular architecture". They criticized climatic authenticity in shaping architectural forms and modernism universality in neglecting the local cultural variables in developing styles. In his writings, Rapop ort (1973) considered a folk tradition as an immediate and unconscious translation of the needs, values, desires, and instincts of any people. He believed that the language of the material culture and the methods of the folk architecture in any nation could answer the design needs instead of the architects, artists, and decorators. He has identified two types of buildings; the first is the primary building that represents a certain degree of technical, economic develop ment and social order. Therefore, the primary building developed in the societies that anthropologists call as primitive. The second is the vernacular buildings, which are pre-industrial constructions, including modern ones.

Here repeatedly, it is necessary to revise the concept of tradition. Rapoport believes that primitive societies are highly traditionalist and the forms that are considered acceptable in society are highly resistant to any change, and this is why continuity shaped like a pattern that resembles all homes built in primitive societies. Therefore, vernacular design means selecting and adjusting. The significant changes and minor differences in vernacular buildings are considerably more comprehensive than primitive ones (1-5). Indeed, vernacular architecture is in harmony with the cultural environment, and social contracts are among the factors that create the norms in it. This kind of architecture is notably time-consuming, so one of the most important of vernacular architecture is its resistance to change. Vernacular architecture is shaped by the desires of a people and the demands of their cultural and physical surroundings without the intervention of architects' ideas (Khakpour et al. 2015, 4) (Figure 2). 


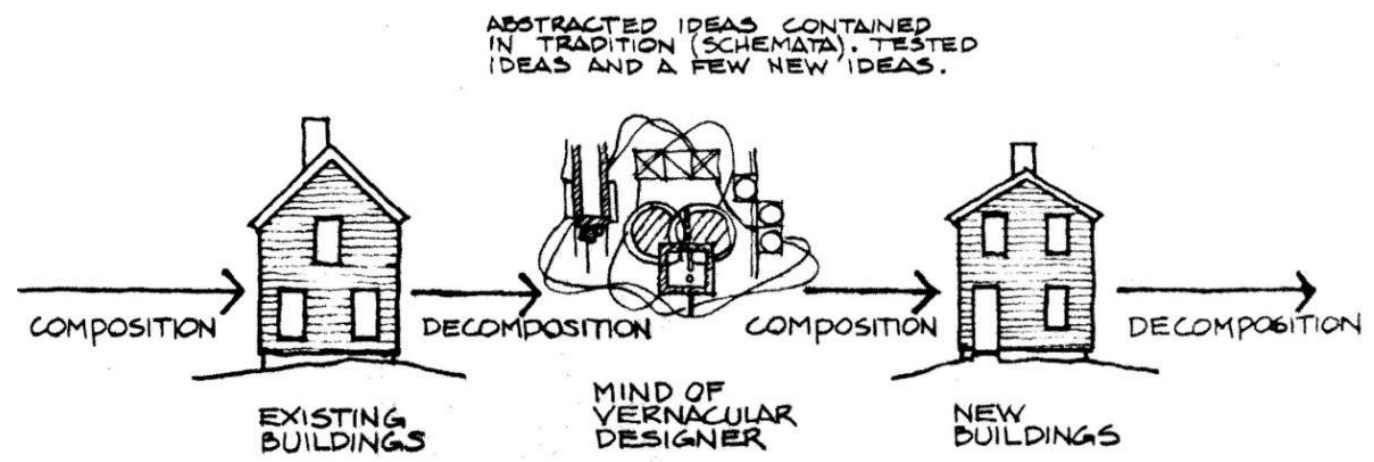

Figure 2. The generative process in the vernacular design method, from Thomas Hubca Source: Domer $(1989,51)$

In the Persian language, the word Boumi as an adjective and Boum as a noun is equivalent to vernacular in English, but not the same. The word eco in ecology has also been translated into Boum in Persian. In the Dehkhoda Persian Encyclopedic Dictionary (Loghatnameh), Boum means temperament, nature and essence, land and region, birthplace, fortress and fence, where one lives, and the area (Dehkhoda 1998, 5085). In almost all of these synonyms, the concept of place can assume. In other words, Boum is an objective phenomenon in Persian culture and not a subjective one. In general, Boum in a geographic sense in Iranian culture consists of three factors: human factors, climatic factors, and material factors that constitute the basis of any civilization in all lands; Human factors performances are depending on the culture and beliefs of each area. The land, the beliefs and demands are revealed in the characteristics of the architectural forms. The climatic factors of each land determine the orientation and quality of its vernacular architecture and define the material or natural elements, the type of texture of each region, and the quality of materials (Zolfagharzadeh and Hessari 2014, 31).

Such a perception of the Boum as a geographic zone is the origin of the prevalent climatic architectural categories in Iran. Its division to the temperate and humid (Caspian shores), cold (western mountains), hot and dry (central plateau), and hot-humid (southern shores) zones have also adapted to the similar climatic architectural typologies. Regarding the physical capacity of each Boum in Iranian architecture tradition, called "eco-friendly" and "selfsufficiency" (Pirnia 2001, 31,32). It should not overlook, however, that Boum and geography are not the same; human interaction with nature and talent presented in the geographical area are components that make up the concept of Boum. Otherwise speaking of nature alone cannot represent the concept of Boum.

In some cases, indigenous people are also referred to as Boumi; most of them often referred to as natives. For example, in exploring the perceptions of sustainable tourism development in Persepolis, although no definition of indigenous people has been provided but often referred to as local people, local community and host people (Najjarzadeh and Nematolahi 2018, 45, 46). In this interpretation, there is a kind of concept pairing - guest/host, local/non-local and the like- which also can be seen on a broader level in insiders and outsiders dualism in Iranian culture. For instance, there are tendencies in Iran that regard western classical architecture as opposed to Iranian architecture using the term Boumi (Suil and Imanin 2015). Western classical architectures have been considered somehow "other" or alien to insiders. The Boumi architecture thus regarded as a kind of homeland and local architecture that differs from what can be called foreign. Here, the notion of identity means resemblance to self and differentiation from others by definition.

Mohammad Mansour Falamaki's, an Iranian scholar, perception of vernacular architecture relies on a kind of synergy that mediated between apparently contradictory 
concepts. Vernacular architecture in his opinions means urban-architectural units that come together in a given territory and with coordination of a form, volume, usage, colouring, the rhythm of masses, and empathy surfaces, as well as harmonies between materials and building systems, individuality and culture, innate unity and mutual respect of environmental behaviours. It signifies independence and social associations (Figure 3) $(2005,17)$. It seems that the suspense between "this" or "that", similarity/difference, norms/taste, freedom of choice/social constraints, and the like is the factor that has enriched vernacular architecture and provided the basis for its growth throughout history. In vernacular architecture, the contrast of function and form is unified. They are a container for conveying cultural messages, everyday life, living experiences, and objects for refining the observer's perception of all emotions and memories.
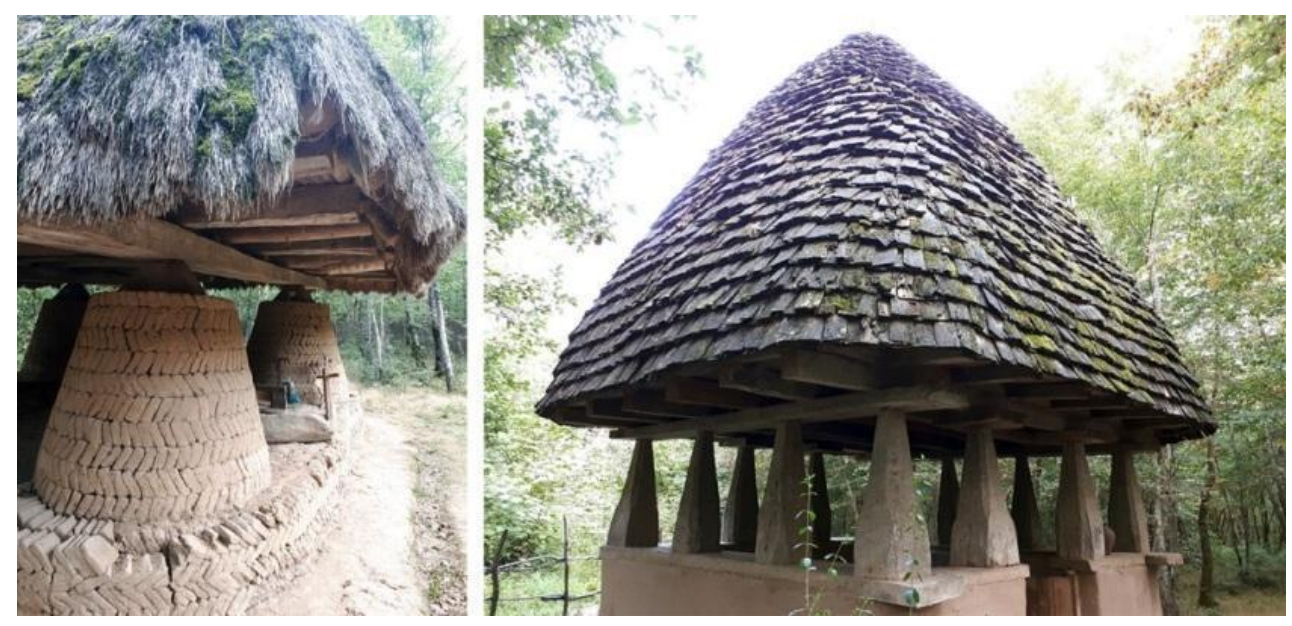

Figure 3. Two examples of vernacular architecture of storage tanks in Guilan, Iran called Kouti Source: Author, 2018

\section{B. Types Of Attitudes Toward Vernacular Architecture Studies}

The emergence of the vernacular notion in theoretical and academic literature, rather than the result of field studies, stemmed from the sociological imperative to name the achievements of a part of society that differed from the literate and elite class. In other words, although the term "vernacular architecture" originated in the nineteenth century and was a subset of twentieth-century historical studies, its origins date back to the seventeenth century. In the late seventeenth century in the United Kingdom, part of the educated group had structured a new cultural standard known as "polite"; they considered the rest of society a subject for study. From 1650 to 1725 they made direct observations on the customs of the populace which were not carefully studied until the nineteenth century (Green 2007, 1). Therefore, the creation of two social classes; the elites, and the populace, were the source of the first studies in the culture and life of another part of the society that later became vernacular.

The sixteenth-century deposed the introduction of the details of Renaissance architecture as a symbol of education, dignity, and power. In the seventeenth century, the new architecture grammar developed among upper classes of the society to influence the overall appearance of a house in detail. In the eighteenth century, vernacular buildings with various localities converted into a transitional or dignified national style. Owners' status became a substitute for the style reform (Cooper 2002, 28). In the twentieth century, Paul Oliver and Amos Rapoport, as one of the leaders of vernacular architecture, consolidated the architectural position concerning culture and to some extent linked architecture to anthropology. However, the direction of vernacular architecture in the twenty first century remains undefined; in the past three decades, we have seen changes in the study of vernacular architecture based on 
folklore attitudes in traditional construction, classification, and ethnology. Such an advance has been driven by a paradigm shift from the study of architectural monuments to conventional and anonymous local buildings (Ara and Rashid 2016, 3). Thus over the last two to three centuries a variety of interpretations of vernacular architecture have emerged; architects, ethnologists, historians, geographers, social anthropologists, sociologists, psychologists, and others each have their approaches to the study of the artificial environment (Lawrence 2013, 19). The diversity of vernacular architectural studies can be classified into at least several sections as follows:

1. Vernacular architecture as the object of aesthetics

2. Vernacular architecture as a biological phenomenon (types and evolution)

3. Vernacular architecture as a material-physical substance (physical explanations)

4. Vernacular architecture as a cultural-sociological reality

5. Vernacular architecture as an anthropological phenomenon

\section{Vernacular Architecture as The Object of Aesthetics}

Although the early roots of vernacular studies were related to the social sphere, studies of vernacular architecture initially had a formalist approach to aesthetics. One of the most pioneering books in this field is a book derived from an exhibition by Bernard Rudofsky (1987) of Architecture without Architecture. His book was full pictures of buildings taken from different cultures and non-industrial societies (Figure 4) rather than using analysis methods to understand the meaning of these buildings or the reasons for their construction and built (Lawrence 2013, 20). Although this book deals with other layers of architecture in often underdeveloped and non-Western societies, the idea still provided in the selection of images shows that the nostalgic desire through Western elitist aesthetics has been the basis of the project. So the result was achieved through the trained eyes that had placed themselves outside, in front of the subject. An important part of the books of travellers and orientalists is full of engravings and photographs that fall into this category. For instance, the Description de l'Egypte was a 22-volume study published between 1809 and 1828, that in most cases pioneered knowledge on any subject, including archaeology, landscape description, cartography, vernacular architecture, and the ordinary people of Egypt, was profoundly influenced by the French elite viewpoints (Whyte 2004, 141) and regarded subjects politically and aesthetically.
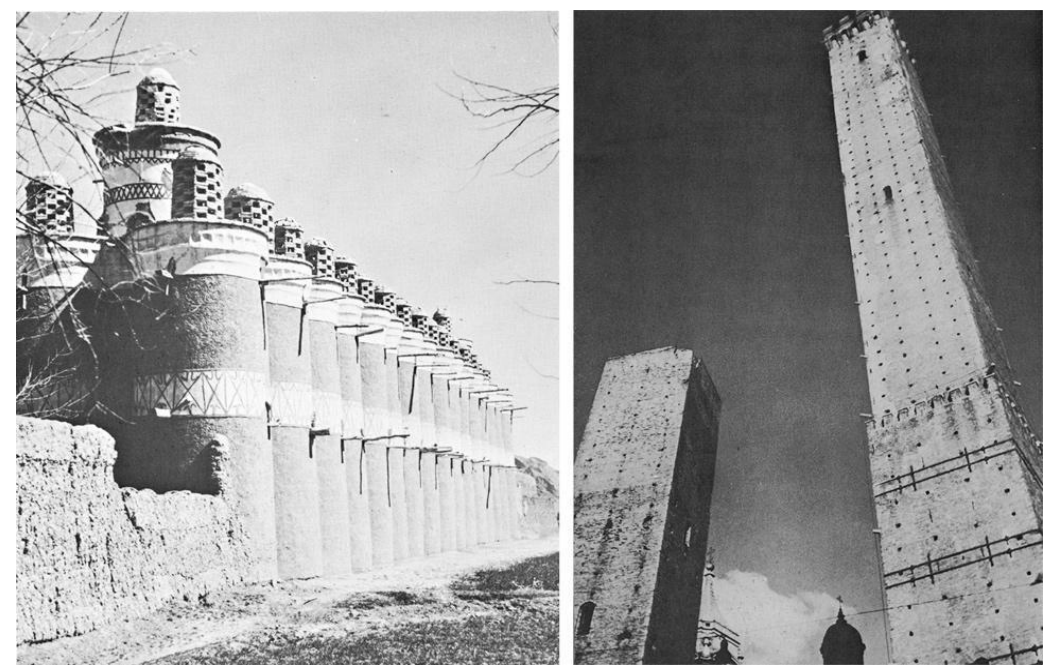

Figure 4. Samples of Rudofsky's Architecture without Architects book; left: pigeon houses in Lanjan near Isfahan, Iran and right: family defence towers in Bologna, Italy Source: Rudofsky $(1987,61,102)$ 


\section{Vernacular Architecture As A Biological Phenomenon (Types And Evolution)}

This regard of vernacular architecture is not outside the formalism. According to Mercer $(1997,9)$, formalism is the basis of any examination of man-made objects because they are ordered by their formal classification. What is referred to as the biological viewpoint is the subject of "species" and "typological developments". In the late eighteenth and early nineteenth centuries, many architectural theorists tried to classify several kinds of architectural objects. Such efforts also highlighted the difference between species and models. For instance, although Rapoport did not develop a specific typology about vernacular architecture, he believed that its design process was one of the diverse models and adaptations. There are numerous different individual styles in primary constructions, so they are not species (Lawrence 2013, 20). In other words, the species in the vernacular buildings are specific to a particular time and region, but the model refers to specific monuments. Hence, in the typology of vernacular architecture, the following should be noted (Ibid): 1architectural composition (layout of the elements); 2- site restrictions and the expected usage; 3- materials and techniques used for construction. There are several studies in this area, for instance, identifying types of rural dwelling in Brittany (Meirion-Jones 1973), the evolution of dwelling types on San Andres Island (Edwards 1991), studying Greek vernacular architecture types (Aalen 1987), and documenting vernacular architecture in Afghanistan (Najimi 2016) are notable. R.W.Brunskill also illustrated vernacular architecture of the Lake Counties (1974) with the system of typology and classification established by the School of Architecture of Manchester University by paying specific attention to plan types ranged from small to large rural domestic houses, cottages and farm buildings (Chesher and Chesher 1974, 8).

\section{E. Vernacular Architecture as a Material-Physical Substance (Physical Explanations)}

In this view, vernacular architecture is considered a kind of physical expression in the sense that the design and development of vernacular buildings could be analyzed based on one or more of its physical factors, such as availability of materials and topography and surrounding. In the UK, according to Lawrence $(2013,23)$, Sidney Addy in 1890s and Charles Innocent in 1910s were the founders of such an idea. This interpretation of vernacular architecture is meant to simplify and reduce the subject to a few elements and cannot contain other concepts. Considering the typology of vernacular architecture based on materials used in the roof structure, walls, and the like, although it may provide a better description of the building, it cannot explain the reasons for its formation and fail to explain why materials preferred over other specimens. For instance, Meeson (2012) studied structural trends in English medieval buildings from dendrochronology. Meirion-Jones (1985), also discussed roofing techniques, trusses types and materials in vernacular buildings of France.

\section{F. Vernacular Architecture As Cultural-Sociological Reality}

Vernacular architecture regarded as a piece of sociological evidence in some researches. This aspect is also embedded in the broader category that somehow addresses the materiality of the architectural evidence. In this view, architecture is a cultural idea that has the materiality needed to shape and transform memory into a schema. Schema is nothing but what can be seen by others. This aspect connects architecture to the whole body of culture (Glassie $1984,8)$ or cultural informant (Heath 1988, 2). From this perspective, paying attention to cultural interests means considering the former mentality and the way the ancients look at the world. That had become depicted in the ultimate form of settlements because it is more than just the result of economic life; it is the pervasive social and cultural environment which affect making any decision and form of housing (Johnson 1997, 19). Here, as Cherry and Green $(2019,8)$ quoted, "imagination and socio-logical theory" are needed.

In North America, cultural geographer, Fred Kniffen explored the idea that folk housing forms might be used to track the course of migrant culture (Wells 1986, 1) or in Ireland, 
Ziebarth (1990) illustrated interwoven of culture and design in Irish vernacular architecture from eighteen to nineteen century using semiotic analysis. Combining cultural geography with vernacular architecture is a new approach; Oranratmanee (2020) explains the dialectic relationships between culture and vernacular dwellings in marginal communities located on the border between southern China and Myanmar.

Investigating the structure of the vernacular building also includes data more than technical notes. For example, they show the skills, craftsmanship, training methods, specialization, mobility, and organization of employees and their links to other professions as well as to workers (Dyer 1997, 1). Vernacular buildings were the product of economics and considered as a financial source for the payment and transportation of materials and crew to their owners; a sign of economic deprivation and a choice between consumption, investment and savings (Ibid). The layout, the interior decorations, and the way the house expanded in line with the growth of the household, all belonged to a social system that somehow embodied the design criteria in the vernacular buildings. Besides, gender studies have also been honoured in vernacular architecture. Compelling studies have likewise focused on the role of women in the design and development of vernacular buildings (Figure 5) (Bernstein and Torma 1991, Williams and Young 1995). This issue, followed by the role of genders affected the formation of vernacular buildings (Kwolek-Folland 1995).

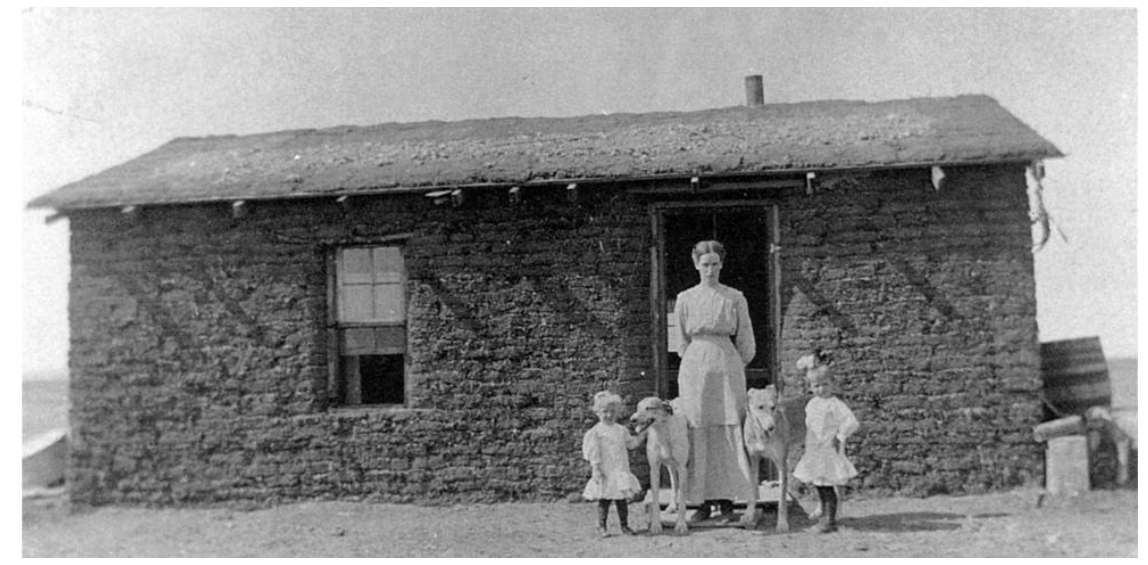

Figure 5. Woman with two children in front of a humble abode house in South Dakota Source: Bernstein and Torma $(1991,65)$

\section{G. Vernacular Architecture As An Anthropological Phenomenon}

Vernacular architecture, anthropology and history are subjects that are indistinguishably linked. As culture and the environment become more interconnected, intertwined and integrated with a spatial-temporal framework, each will inevitably complement the other. The question, however, is how architecture and anthropology work together to inform each other (Ara and Rashid 2016, 1). What will be the anthropological approach to vernacular architecture? Although the relationship between vernacular architecture and culture is clear, the link between vernacular architecture and anthropology remains unstable. Explaining this lacks a look at romantic phenomenology, particularly in Germany. Nietzsche defined human beings as landless as a rootless animal, which meant a lack of knowledge and folk tradition and placed man in nature or the cosmos. Heidegger was also looking for a way to find a background for Heimat's symbolic shaping resources.

Based on German Romanticism, the Heimat concept supports the idea that history does not evolve based on mere sequences of specific events but that history includes the stable anthropological interactions that exist between housing, settlements, and landscapes (GarcíaEsparza 2015, 2, 3). Vernacular shelters are surviving and valuable witnesses to the historical memory of any place that fits into the values, economics, and lifestyles of the cultures that 
produce them (Philokyprou 2011, 8). Vernacular architecture is a document that, along with other written records such as agreements and covenants, can be considered as a source for tracing changes in building-residence-landlords relationships (Ward 1994). Maps also have a particular value in charting how vernacular architectural boundaries sever or coincide with national, cultural or ethnic boundaries (Vellinga 2003).

\section{H. Vernacular Architecture \& Lessons For Contemporary Design}

In addition to the five trends presented formerly in this research, vernacular architecture also contains valuable lessons and ideas for today's world and contemporary design. Vernacular architecture can be considered as a solution to the earthquake problem in many earthquake-prone countries. For example, maintaining structural integrity of buildings from the evidence of the 2015 earthquake in Nepal demonstrates that unexpectedly the wooden traditional structures work well in comparison with the modern materials (Adhikary 2016). Vernacular architecture also has many ideas for sustainable and climate-friendly design. Many studies try to find solutions for climate comfort from vernacular architecture (for instance, see Molodin 2016, Gokarakonda and Kumar 2016, Al-Qawasmi 2016). Strategies and tactics which were recommended by Motealleh, Zolfaghari, and Parsaee (2018) for sustainable design in the city of Bushehr in Iran are the results of studying and classifying vernacular solutions in the architecture of that region. Another similar study has been done in the residential historic core of Erbil, Iraq as a World Heritage Site to adapt it to the modern city and to energy saving and sustainable development (Algburi and Beyhan 2019). To provide design approaches for sustainable construction, the range of different passive solar techniques used in Portuguese vernacular architecture has been suggested by Fernandes et al. (2015), too. Even small and remote villages can have solutions for today's architecture; a successful and recent example being Karahan and Davardoust (2020)'s research for a region called Uzundere intrict in Turkey. They showed the optimized usage of materials, construction techniques and climatic considerations occurred in this region during centuries.

Vernacular architecture could be considered as a solution for overcoming the housing crisis in communities today. For instance, Habibi (2019) demonstrate ademonstratesor using bamboo as a structural material for low-income and affordable housing whichhousing, which the financial stability and economic sustainability of low-income families. Vernacular architecture not only provides solutions for the low-income class, but can also be a serious issue for the social upper classes; A new study in the region of Catalonia in Spain by Alcindor and Coq-Huelva $(2020,684)$ explores the various ways in which tradition is reclaimed, recovered, and reinvented and has shown that "the rehabilitation of vernacular rural buildings generates a type of housing completely different from traditional constructions in its conception, functionality, design, materials, and construction processes." The issue of the working class, which needs temporary housing per year, can also be solved with solutions from local architecture. Durand (2020), analysed the analyzed vernacular architecture in the way seasonal employers deal with the multiple and sometimes conflicting temporalities of contemporary lives and motilities in Vanuatu with respect to both imported and local materials such as concrete, leaves, vines and wood.

In this way, new concepts or terms are being formed, which Zhao and Greenop (2019) called them 'neo-vernacular' (buildings with a vernacular appearance with contemporary methods and materials) and 'semi-vernacular' (reusing or renovating vernacular buildings in combination with modern and traditional building techniques). These new trends try to reimaging the vernacularity and attempt to challenge the dichotomies inherent in earlier definitions and representations of the vernacular (Zhao and Greenop 2019).

\section{RESULT AND DISCUSSION}


Vernacular architecture has been the focus of experts, researchers, architects and planners for the past few decades. What matters is their perspective and viewpoints toward the main definitions and concepts. In this research, more emphasis was placed on theoretical approaches in the previous studies. The findings of this study categorized at least five significant approaches in vernacular architecture; These approaches considered vernacular architecture as an object of aesthetics, a biological phenomenon (types and evolution), a material-physical substance (physical explanations), a cultural-sociological reality, and finally as an anthropological phenomenon. Results show that these tendencies can be classified into the following concepts, which can clarify our understanding of the subject:

A. From documentation to interpretation: Primary, a significant part of the vernacular architecture studies in early decades devoted to documentation: categorisation by type, species, shape, usage, location, materials and the similar in one hand and its evolution and physical explanations of building elements, on the other. Efforts are yet underway to document vernacular heritage, especially in developing countries. Regarding vernacular architecture as a biological phenomenon or a material-physical substance it falls into this tendency. However, in recent years socio-cultural or anthropological attitudes seek interpretation, not description. And in the future, these issues will be more critical to researchers than previously. Phenomenology, hermeneutics, semiotics, gender studies, and feminism set new horizons for vernacular architectural studies.

B. From objectivity to subjectivity: Early approaches had an objective attitude of vernacular architecture; a phenomenon that could be assessed and recognized in its external materiality. Limiting the analysis of vernacular buildings to aesthetic and formal features is the result of this viewpoint. However, the buildings embodied and depicted symbolic and multiple cultural, social, economic and political messages, and were not the only aesthetic responses to their environmental limitations and capabilities. Thus, later studies have a subjective view of the issue. This paradigm shift was accelerated, especially with the formation of cultural geography in the 1970s.

C. From primitive to ordinary: Although the vernacular architecture is rooted in primitive, indigenous, native, and local communities, the notion of vernacular has shifted to the ordinary people in the present days. Ordinary people, who do not necessarily accept or support the aesthetic and styles of the elite, created a kind of architecture that can be considered the vernacular architecture of the twentieth century. Ethnic, racial, and gender groups in various societies seek to express their beliefs in the built environment. These can be called Folks.

D. From ignoring to applying: Attempts to ignore indigenous and native achievements under the pretext of progress and using modern technology have given way to learning and applying local and traditional solutions in design and architecture. The rapid growth of urbanization, scarcity of resources, increasing environmental pollution on local and global scales no longer leave room for unresponsive modern architectural design methods. The issue of sustainable development, reduction of energy consumption and the use of passive design methods are reflected in various studies in the field of natural ventilation, daylight and recyclable and renewable materials. Today, by redefining the concept of vernacularity, efforts are being made to extract social solutions to solve cultural, economic and residential problems from the vernacular architectural heritage. These are issues that were unimaginable at the beginning of the twentieth century. Vernacular architecture is now seen not only as a heritage, but also as a source of inspiration for the contemporary world and the creation of a better future for human habitation. 


\section{CONCLUSION}

Vernacular architecture is a sociological phenomenon that emerged as a result of the elites' look of the achievements of the classes of society which did not conform to formal and aesthetics of the polite architecture but formed by their everyday life. Vernacular architecture is a mental construct that places its dynamism, fluidity, and multi-dimensionality against the static, quiet, and monotonous formal architecture. Unlike conventional architecture that trained on sets of academic models and defaults, a vernacular architecture developed on a freely reconstruction and modification based on creativity, need, and application. Vernacular architecture based itself on native human being's understanding of space, nature, and the forces within it. It is a subjective phenomenon, although it is objective. It does not rely on formal contracts and is free to operate.

Despite the importance of cultural symbols and signs in their forms of decoration and shape, the aesthetics of vernacular architecture are also a consequence of climate. Therefore, the shape of buildings, the orientation, the grouping of individuals together, materials and colours, the technology of construction and polishing all come to be depicted in aesthetics form that has been in constant interaction and harmony with nature. To a large extent, vernacular architecture is still valued with the elite conceptual aesthetics frameworks yet measured, defined, and protected based on elitist principles. A relevant part of research conducted in the adaptive tradition, refurbishment, thermal preferences, sustainability and post-occupancy measurements of vernacular constructions are yet an elite interest and passion that was not discussed in this study.

However, in this study, a review of vernacular architecture in the contemporary world showed that in at least the last decade, new and serious efforts have been made to reread vernacular architecture as a solution for overcoming community problems based on tests of local experiences instead of general and universal advice. The importance of vernacular architecture of sustainable development and design has already been proven today, but its scale and implementation agenda still needs more attention. Despite all these advances, a significant portion of the world's vernacular architectural heritage is still being destroyed, and the need for documentation has not been met. The role of gender in future studies in this field will continue to be prominent and cultural differences should be considered as a topic for better understanding of societies in terms of coexistence and friendship. Future studies could focus on the impact of political and economic theories, as well as the effects of war and military conflict on vernacular architecture in the twentieth century. Examining the experiences of countries that have faced rapid economic growth in recent decades can also be useful for other developing nations.

\section{Acknowledgment}

This research was supported by the Research and Technological Affairs of Shiraz University of Arts under Grant number 1761/98/8 for a research project entitled Representation of Landscape and Vernacular Architecture in Sohrab Sepehri's Drawings.

\section{REFERENCES}

Aalen, F. H. A. 1987. "Review Article: Greek Vernacular Architecture." Vernacular Architecture no. 18 (1):41-50. doi: 10.1179/vea.1987.18.1.41.

Adhikary, Nripal. 2016. "Vernacular architecture in post-earthquake Nepal." International Journal of Environmental Studies no. 73 (4):533-540. doi: 10.1080/00207233.2016.1179011.

Al-Qawasmi, Jamal. 2016. "Vernacular as a renewable resource: toward region-specific architecture in Saudi Arabia, a case from KFUPM." Architectural Engineering and Design Management no. 12 (2):81-96. doi: 10.1080/17452007.2015.1109497.

Alcindor, Mónica, and Daniel Coq-Huelva. 2020. "Refurbishment, vernacular architecture and invented traditions: the case of the Empordanet (Catalonia)." International Journal of Heritage Studies no. 26 (7):684-699. doi: 10.1080/13527258.2019.1678054. 
Algburi, Omar, and Figen Beyhan. 2019. "Climate-responsive strategies in vernacular architecture of Erbil city." International Journal of Environmental Studies no. $76 \quad$ (5):745-763. doi: 10.1080/00207233.2019.1619324.

Alpago Novello, Adriano. 2005. "Drinking from Your Well; Introducing The Issues of Vernacular Architecture, Its Current Meaning and Perspectives." In Architectettura Popolare, edited by FazaScientificandCulturalInstitute, 22-49. Tehran: Faza.

Ara, Dilshad, and Mamun Rashid. 2016. "Imaging Vernacular Architecture: A Dialogue with Anthropology on Building Process." Architectural Theory Review no. $21 \quad$ (2):172-195. doi: 10.1080/13264826.2017.1349817.

Ashish Ganju, M. N. 2016. "Documentation and conservation of vernacular architecture: conservation and continuity." International Journal of Environmental Studies no. 73 (4):484-490. doi: 10.1080/00207233.2016.1179012.

Bernstein, Rebecca Sample, and Carolyn Torma. 1991. "Exploring the Role of Women in the Creation of Vernacular Architecture." Perspectives in Vernacular Architecture no. 4:64-72. doi: 10.2307/3514222.

Brunskill, R. W. 1981. Traditional Buildings of Britain: Introduction to Vernacular Architecture. London: Orion Publishing Group.

Cherry, Martin, and Adrian Green. 2019. "Vernacular Architecture at 50: Towards the Study of Buildings in Context." Vernacular Architecture no. 50 (1):1-17. doi: 10.1080/03055477.2019.1663471.

Chesher, F. J., and V. M. Chesher. 1974. "Vernacular Architecture of the Lake Counties, A Field Handbook." Vernacular Architecture no. 5 (1):8-8. doi: 10.1179/vea.1974.5.1.8.

Cooper, Nicholas. 2002. "Display, Status and the Vernacular Tradition." Vernacular Architecture no. 33 (1):28-33. doi: 10.1179/vea.2002.33.1.28.

Cromley, Elizabeth. 2008. "Cultural embeddedness in vernacular architecture." Building Research \& Information no. 36 (3):301-304. doi: 10.1080/09613210801902995.

Damyar, Sajad, and Masoud Nari Ghomi. 2012. "The Comparative Study of the Space Concept in the Vernacular Architecture and Modern Architecture." Honar-Ha-Ye-Ziba: Memary Va Shahrsazi no. 17 (1):65-72. doi: 10.22059/jfaup.2012.29698.

Dehkhoda, Ali Akbar. 1998. Loghatname (Encyclopedic Dictionary). Edited by Mohammad Moin and Jafar Shahidi. 16 vols. Vol. 4. Tehran: Tehran University.

Domer, Dennis. 1989. "The Old and New of Vernacular Architecture - A Review Essay." Journal of Architectural Education no. 42 (4):45-56. doi: 10.1080/10464883.1989.10758540.

Durand, Marie. 2020. "Concrete Time: Material Temporalities and Contemporary Mobilities in the Vernacular Architecture of Northern Vanuatu, Melanesia." Fabrications no. 30 (1):92-109. doi: 10.1080/10331867.2020.1721089.

Dyer, Christopher. 1997. "History and Vernacular Architecture." Vernacular Architecture no. 28

(1):1-8. doi: 10.1179/030554797786050428.

Edwards, Jay. 1991. "The Evolution of a Vernacular Tradition." Perspectives in Vernacular Architecture no. 4:75-86. doi: $10.2307 / 3514223$.

Falamaki, Mohammad Mansour. 2005. "Vernacular Architecture in Iran." In Architectettura Popolare, edited by FazaScientificandCulturalInstitute, 73-94. Tehran: Faza.

Fernandes, Jorge, Ricardo Mateus, Luís Bragança, and José Júlio Correia da Silva. 2015. "Portuguese vernacular architecture: the contribution of vernacular materials and design approaches for sustainable construction." Architectural Science Review no. 58 (4):324-336. doi: 10.1080/00038628.2014.974019.

García-Esparza, Juan A. 2015. "Epistemological paradigms in the perception and assessment of vernacular architecture." International Journal of Heritage Studies no. 21 (9):869-888. doi: 10.1080/13527258.2012.666755.

Garfinkel, Susan. 2006. "Recovering Performance for Vernacular Architecture Studies." Perspectives in Vernacular Architecture no. 13 (2):106-114.

Glassie, Henry. 1984. "Vernacular Architecture And Society." Material Culture no. 16 (1):4-24.

Gokarakonda, Sriraj, and Ankit Kumar. 2016. "Passive Architectural Design Index applied to vernacular and passive buildings." International Journal of Environmental Studies no. 73 (4):563-572. doi: 10.1080/00207233.2016.1178982.

Green, Adrian. 2007. "Confining the Vernacular: The Seventeenth-Century Origins of a Mode of Study." Vernacular Architecture no. 38 (1):1-7. doi: 10.1179/174962907X247985.

Groth, Paul. 1999. "Making New Connections in Vernacular Architecture." Journal of the Society of Architectural Historians no. 58 (3):444-451. doi: 10.2307/991538. 
Habibi, Shahryar. 2019. "Design concepts for the integration of bamboo in contemporary vernacular architecture." Architectural Engineering and Design Management no. $15 \quad$ (6):475-489. doi: 10.1080/17452007.2019.1656596.

Heath, Kingston Wm. 1988. "Defining the Nature of Vernacular." Material Culture no. 20 (2/3):1-8.

Heath, Kingston Wm. 2003. "Defining the Nature of Vernacular." Material Culture no. 35 (2):48-54.

Johnson, Matthew. 1997. "Vernacular Architecture: The Loss of Innocence." Vernacular Architecture no. 28 (1):1319. doi: $10.1179 / 030554797786050653$.

Karahan, Faris, and Sanaz Davardoust. 2020. "Evaluation of vernacular architecture of Uzundere District (architectural typology and physical form of building) in relation to ecological sustainable development." Journal of Asian Architecture and Building Engineering no. 19 (5):490-501. doi: 10.1080/13467581.2020.1758108.

Khakpour, Mojgan, Mojtaba Ansari, Ali Sheikhmehdi, and Mahmood Tavoosi. 2015. "Socio-cultural Characteristics of the Vernacular Houses." Journal of Housing and Rural Environment no. 34 (149):3-14.

Kwolek-Folland, Angel. 1995. "Gender as a Category of Analysis in Vernacular Architecture Studies." Perspectives in Vernacular Architecture no. 5:3-10. doi: 10.2307/3514241.

Lanier, Gabrielle M. 2009. "Vernacular Architecture in the Twenty-First Century: Theory, Education and Practice." Journal of Architectural Education no. 63 (1):160-161. doi: 10.1111/j.1531-314X.2009.01050.x.

Lawrence, Roderick J. 2013. "The Interpretation of Vernacular Architecture." Vernacular Architecture no. 14 (1):19-28. doi: 10.1179/vea.1983.14.1.19.

Mann, Dennis Alan. 1985. "Between Traditionalism and Modernism; Approaches to a Vernacular Architecture." Journal of Architectural Education no. 39 (2):10-16. doi: 10.1080/10464883.1985.10758388.

Meeson, Bob. 2012. "Structural trends in english medieval buildings: New insights from dendrochronology." Vernacular Architecture no. 43 (1):58-75. doi: 10.1179/0305547712Z.0000000006.

Meirion-Jones, Gwyn I. 1973. "Settlement and Vernacular Architecture in Brittany." Vernacular Architecture no. 4 (1):3-6. doi: 10.1179/vea.1973.4.1.3.

Meirion-Jones, Gwyn I. 1985. "The Vernacular Architecture of France: An Assessment." Vernacular Architecture no. 16 (1):1-17. doi: 10.1179/vea.1985.16.1.1.

Mercer, Eric. 1997. "The Unfulfilled Wider Implications of Vernacular Architecture Studies." Vernacular Architecture no. 28 (1):9-12. doi: 10.1179/030554797786050437.

Molodin, Alexander V. 2016. "The contribution of multi-level heating strategies in thermal performance of vernacular architecture in Chukotka." Architectural Science Review no. 59 (2):71-80. doi: 10.1080/00038628.2015.1078223.

Motealleh, Parinaz, Maryam Zolfaghari, and Mojtaba Parsaee. 2018. "Investigating climate responsive solutions in vernacular architecture of Bushehr city." HBRC Journal no. 14 (2):215-223. doi: 10.1016/j.hbrcj.2016.08.001.

Najimi, Abdul Wassay. 2016. "Studies in vernacular architecture in Afghanistan: training in conservation of historic structures in Kabul Old City." International Journal of Environmental Studies no. 73 (4):512-523. doi: 10.1080/00207233.2016.1178985.

Najjarzadeh, Mohammad, and Majid Nematolahi. 2018. "Structural Modeling of Factors Influencing Local Residents' Perception Towards Supporting Sustainable Tourism Development in Persepolis." Journal of Applied Sociology no. 29 (1):41-62. doi: 10.22108/jas.2017.98649.

Oliver, Paul. 1996. "Vernacular Studies: Objectives and Applications." Traditional Dwellings and Settlements Review no. 8 (1):12-12.

Oranratmanee, Rawiwan. 2020. "Cultural geography of vernacular architecture in a cross-cultural context: houses of the Dai ethnic minority in South China." Journal of Cultural Geography no. 37 (1):67-87. doi: 10.1080/08873631.2019.1658441.

Philokyprou, Maria. 2011. "Teaching Conservation and Vernacular Architecture." Journal of Architectural Conservation no. 17 (2):7-24. doi: 10.1080/13556207.2011.10785086.

Pirnia, Mohammad Karim. 2001. Stylistics of Iranian Architecture. Tehran: Pajohandeh-Memear.

Rapoport, Amos. 1973. Pour une Anthropologie de la Maison. Translated by Maurin Schlumberger: Dunod

Roberts, Judith. 1996. "Researching the vernacular garden." Landscape Research no. 21 (2):175-187. doi: 10.1080/01426399608706484.

Rudofsky, Bernard. 1987. Architecture without architects: A short introduction to non-pedigreed architecture: Albuquerque: University of New Mexico Press.

Suil, Zafarmandi , and Nadia Imanin. 2015. "Roman architecture versus vernacular architecture, a study of the so called classical tendencies in contemporary Tehran architecture." Soffeh no. 25 (71):27-50.

Vellinga, Marcel. 2003. "Drawing Boundaries: Vernacular Architecture and Maps." Traditional Dwellings and Settlements Review no. 14 (2):21-31. 
Ward, K. T. 1994. "Covenants in Conveyancing Instruments: A Note for the Vernacular Architectural Historian." Vernacular Architecture no. 25 (1):16-19. doi: 10.1179/vea.1994.25.1.16.

Wells, Camille. 1986. "Old Claims and New Demands: Vernacular Architecture Studies Today." Perspectives in Vernacular Architecture no. 2:1-10. doi: 10.2307/3514311.

Whyte, Ian D. 2004. Landscape and History since 1500: Reaktion Books.

Williams, Michael Ann, and M. Jane Young. 1995. "Grammar, Codes, and Performance: Linguistic and Sociolinguistic Models in the Study of Vernacular Architecture." Perspectives in Vernacular Architecture no. 5:40-51. doi: $10.2307 / 3514244$.

Zhao, Xiaoxin, and Kelly Greenop. 2019. "From 'neo-vernacular' to 'semi-vernacular': a case study of vernacular architecture representation and adaptation in rural Chinese village revitalization." International Journal of Heritage Studies no. 25 (11):1128-1147. doi: 10.1080/13527258.2019.1570544.

Ziebarth, Ann C. 1990. "Irish-Vernacular Architecture: An Illustration of Semiotic Analysis." Housing and Society no. 17 (1):27-34. doi: 10.1080/08882746.1990.11430057.

Zolfagharzadeh, Hasan, and Pedram Hessari. 2014. "Ecological View to the Architecture of Habitats." Journal of Housing and Rural Environment no. 33 (145):29-44. 